\title{
貯水池下流部に堆積した微細粒土砂の巻き上げ 特性に関する実験的研究 \\ EXPERIMENTAL STUDY ON EROSION OF COHESIVE SEDIMENTS SILTED IN DOWNSTREAM PARTS OF RESERVOIRS
}

\author{
角 哲也 1 井口真生子 $2 \cdot$ 藤井智康 ${ }^{3}$ \\ Tetsuya SUMI, Makiko IGUCHI and Tomoyasu FUJII
1正会員 工博 京都大学助教授 大学院工学研究科社会基盤工学専攻 ( $7606-8501$ 京都市左京区吉田本町)
2学生会員 工修 博士後期課程 京都大学大学院工学研究科 (株式会社ハイドロソフト技術研究所)
( ( 550-0015 大阪市西区南堀江1-7-4)
3理博 奈良教育大学助教授 教育学部地学教室 ( 7630 - 8528 奈良市高畑町)

\begin{abstract}
Erosion processes of cohesive sediments in reservoirs are studied experimentally as a basic study for fine sediment management in reservoir. The relationships between their critical shear stresses and water contents are liner on log-log paper, which is the same trend as those on cohesive sediments in lakes and river mouths. The relationship between critical shear stress and water content varies in sediments and it can be estimated from its liquid limitation. Since liquid limitation mainly depends on ignition loss and median particle diameter which are usually measured by a dam administrative office every year, those data could help to discuss on erosion process of cohesive sediments in reservoir before detail investigation.
\end{abstract}

Key Words : Reservoir sediment management, erosion of cohesive sediment, critical shear stress, liquid limit, water content, ignition loss, median particle diameter

\section{1.はじめに}

近年，集中豪雨による洪水が多く発生し， また一方では長期的な渴水が顕在する中, 㕛 ムの貯水効果が果たす役割が再認識されてい る. 流入土砂の比較的多いダムの貯水容量の 維持には貯水池土砂管理が必要不可欠である．

典型的なダムの堆砂形状を図-1に示すが， 貯水池内の土砂管理として一般的に対象とな るのは，中・上流部の砂磁主体の土砂である その理由として, この位置の堆砂は, 初期か ら有効貯水容量減少に影響を及ぼすこと，水 位低下時は掘削しやすいこと，掘削した土砂 は骨材, 盛土材, 河川供給材などとして利用 しやすいことが挙げられる．一方，将来的に は，下流部の粘土・シル卜主体の微細粒土砂 の管理も考えていかなければならない .

下流部の水平に堆積した土砂は密度流堆積 層と呼ばれ，流入した微細粒土砂が長時間か けて，沈降・堆積して形成された層である． 密度流堆積層の特徵は, 自然含水比が非常に 高く，有機物・栄養塩が多く含まれることで

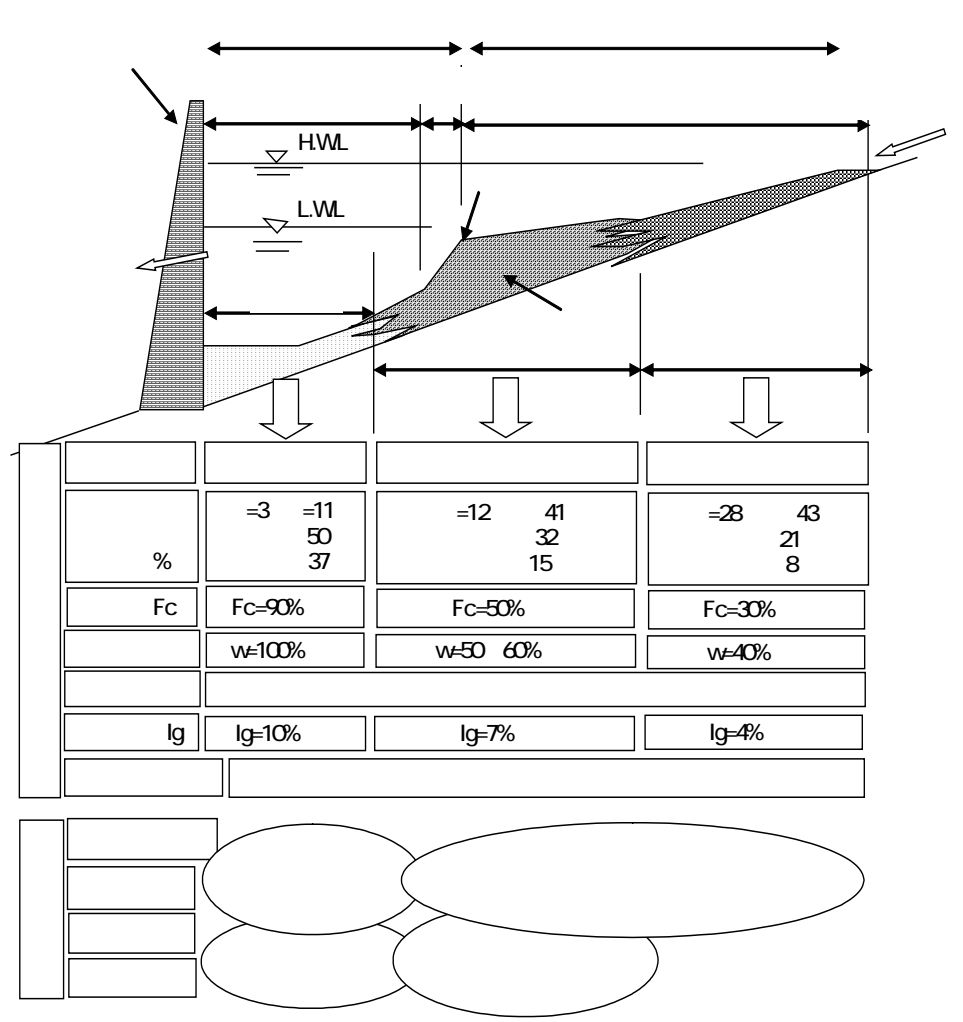

图-1 父ム堆積土砂の性状と有効利用方策1) 
ある.图-1に示されたように，肥料・客土などへの 有効利用が考えられるが，含水比が高いことから取 り扱いが難しく，処理にコストがかかる．この有機 物を多く含む微細粒土砂は貯水池底部の貧酸素状態 で長期間堆積している間に変質し, 大量に下流に放 流されると下流河川環境に影響を与えるお光れがあ る.また，積極的な対策を行わない場合も，堆砂が 進行してこの堆積層上面が底部放流管敷高に近付く と定期的な巻上げが生じる可能性が出てくる. 兴こ で, 貯水池土砂管理の観点からは, 流入した微細粒 土砂はできるだけ速やかに下流へ通過させるのか望 ましい .これを実現させる対策として, 密度流排出 と新鮮な浮泥を再浮上させて放流する手法の 2 つが 考えられる .

密度流排出は, 流入した高濁度水か貯水池内をあ まり拡散せずに密度流となって流下する特性を利用 して, 公堤体に到達するタイミングに併せてゲー 卜放流などにより効果的に排出するもので，中国の 父貯水池で多く採用されている. 貯水池内の密度 流挙動に関する研究 ${ }^{2)}$ は多くなされており, 光の挙 動は解明されてきているが, ダムにより, 密度流が 発生しにくい場合や, 文么の運用上密度流到達まで に洪水放流が終了してしまう場合などは, 密度流排 出は難しい。

2つ目の方法は, 新鮮な堆積状態のうちに, 後続 の洪水時に再浮上させて底部放流管から放流して， 土砂を順次交換させるものである .これについては， 過去の研究事例はなく, 基礎的研究から取り組んで いかなければならない .

以上のことから , 今後, 明らかにすべき事項とし て大きく次の3つが挙げられる .

(1) 密度流堆積層における微細粒土砂の堆積・圧密 過程の経時変化

(2) 微細粒土砂の粒度分布, 有機物含有量, 含水比 などの土砂の特性に対する巻き上げ条件

(3) 貯水池底部に発生する流速場。つまり，流入量， 成層状態, 流入土砂濃度, 堆砂速度および底部 放流管敷高に対する流速，継続時間と光の発生 頻度

(1)ついては，通常の採泥やボーリングでは測定 できないため, 現地での浮遊泥密度測定 ${ }^{3)}$ が必要で ある. (3)については, 現地観測と貯水池内流動シ ミュレーションにより把握できるであろう. 本研究 では，(2)の巻き上げ特性について取り上げる .

まず，密度流堆積層の微細粒土砂を採取し，光の 基本的性質を調べた。次に, 流送実験を行い, 巻き 上げ特性について, 既往の湖沼や河口の底泥の流送 実験結果と比較し，考察を加えた。なお，二れ以降， 密度流堆積層の微細粒土砂を湖沼や河口の堆積物と 同樣に底泥と記す．ただし，貯水池内の底泥で有機 分の比較的少ないものは, 底泥から連想されるよう なへドロ状態ではなく，粘土に近いものである .

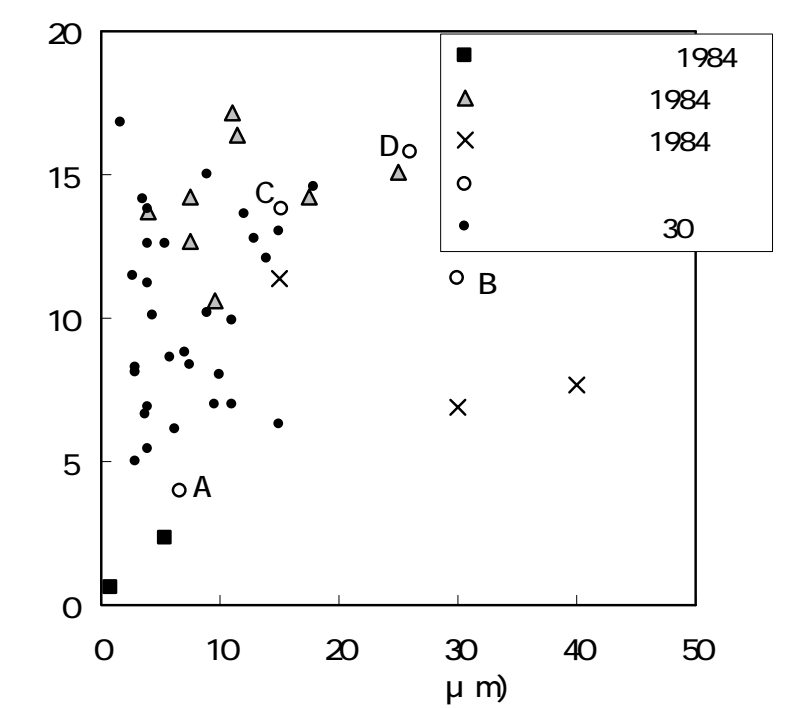

図-2 底泥の中央粒径および強熱減量

\section{2 . 研究の手法}

\section{（1）貯水池の底泥の特性}

図-2は貯水池の底泥の特徵を中央粒径と強熱減量 から見たものである.ははダム管理所が毎年行って いる底質調査あるいはボーリング調査のうち，下流 部に堆積した土砂のデータである.○は今回実験を 行った 4 ダム (A〜D, 詳細は後述) のデータである . なお，㚇の他のデータは大坪年が市販の粘土, 湖沼 および河口の底泥で実験した結果である .

貯水池の底泥の強熱減量は, 今回の対象4父么を 含め， $4 \%$ から $17 \%$ と広く分布している . 後述する が，この有機物含有量の違いによる底泥の性質の違 いは大きい .一方 , 今回の対象4父而中央粒径は レーザー分析で約7 $\mu$ mから30 $\mathrm{m}$ 範囲であるのに

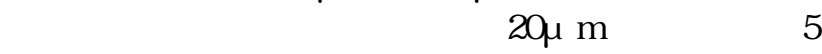
$\mu \mathrm{m}$ 前後と小さいものが多い.ただし，これらの中 には沈降分析によるものが含まれており，レーザー 分析よりも小さめに評価されている可能性がある .

湖沼の底泥については, 粒径は同樣の分布である が, 強熱減量は高い傾向にある.一方, 河口の底泥 については, 強熱減量は低いが, 中央粒径は大きい . 市販の粘土については, 強熱減量は非常に小さく, 中央粒径も小さい.この樣に各底泥には個々の傾向 が見られるが, 貯水池の底泥の分布は広く，乥れ光 れに共通するところがある。したがって，これらの 研究成果は貯水池の底泥の巻き上げ特性を理解する のに大いに参考になると考えられる．

\section{（2）底泥の巻き上げ特性と限界掃流力}

微細粒子は砂粒とは異なり重力, 粘着力や凝集力 などの表面力が支配的になる . Li ckら ${ }^{5}$ の石英の微

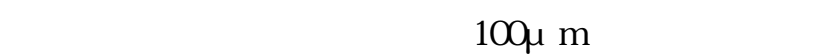
では粘着力は重力より大きくなることが示されてい る.さらに, 有機物の含有量や吸着陽イオンの種類 により, 粘着力や凝集力が変化し, 弚の性質を複雑 にしている．弚れゆえ，底泥の限界掃流力および浸 
表-1 対象ダムの底泥の基礎的物性値

\begin{tabular}{|c||c|c|c|c|}
\hline & ダム $\mathrm{A}$ & ダム $\mathrm{B}$ & ダム C & ダム D \\
\hline \hline 中央粒径 $(\mu \mathrm{m})$ & 6.7 & 29.9 & 15.2 & 26.1 \\
\hline 強熱減量 $(\%)$ & 4.0 & 11.4 & 13.8 & 15.8 \\
\hline 液性限界 $(\%)$ & 49.0 & 142.3 & 175.3 & 177.7 \\
\hline 土粒子密度 $\left(\mathrm{g} / \mathrm{cm}^{3}\right)$ & 2.794 & 2.514 & 2.513 & 2.526 \\
\hline 自然含水比 $(\%)$ & 85.2 & 337.8 & 363.8 & 424.1 \\
\hline
\end{tabular}

表- 2 底泥および粘土の種類と各物性值 (大坪 ${ }^{4)}$ )

\begin{tabular}{|c|c|c|c|c|c|}
\hline & & $\begin{array}{c}\text { 中央粒径 } \\
(\mathrm{n} \mathrm{m})\end{array}$ & $\begin{array}{c}\text { 強熱減量 } \\
(\%)\end{array}$ & $\begin{array}{c}\text { 液性限界 } \\
(\%)\end{array}$ & 粘土の分類 \\
\hline 1 & Koalin & 5.5 & 2.3 & 51.1 & \multirow{2}{*}{ 市販粘土 } \\
\hline 19 & Mntmorillonite & 0.8 & 0.6 & 354.0 & \\
\hline 20 & Kasumi Mud1 & 11.0 & 17.1 & 212.5 & \multirow{8}{*}{ 湖沼泥 } \\
\hline 27 & Inbanuma Mud & 9.5 & 10.6 & 206.0 & \\
\hline 28 & Teganuma Mud & 17.5 & 14.2 & 253.1 & \\
\hline 29 & Ushikunuma Mud & 11.5 & 16.4 & 208.8 & \\
\hline 30 & Hinuma Mud & 7.5 & 12.7 & 239.6 & \\
\hline 31 & Suwako Mud & 7.5 & 14.3 & 232.1 & \\
\hline 32 & Yunoko Mud & 4.0 & 13.7 & 250.6 & \\
\hline 33 & Harunako Mud & 25.0 & 15.1 & 150.7 & \\
\hline 34 & Nakagawa Mud & 15.0 & 11.4 & 119.6 & \multirow{3}{*}{ 河口泥 } \\
\hline 35 & Dojimagawa Mud & 40.0 & 7.7 & 59.2 & \\
\hline 36 & Tosaborigawa Mud & 30.0 & 6.9 & 68.7 & \\
\hline
\end{tabular}

食速度に関する統一された式はないが, 既往の研究 成果から多くの知見が得られている .

ぞのう今回注目すべき結果は，

(1) 底泥の限界掃流力と含水比（もしくは, 間隙比, 空隙率など）(累乗関係がみられる ${ }^{4,6), 71,8)}$.つ まり，同じ成分の底泥であっても，堆積状態 (経過時間) が異なると, 弚の限界掃流力は大 きく異なる。

(2) 底泥の巻き上げ特性は有機物の含有量 ${ }^{4)}$ と粒径5) が関連している．つまり，強熱減量と粒度分布 が分かれば，大まかな巻き上げ特性が予測でき る。

(3) 回転粘度計やベーンせん断試験で測定された降 伏値と限界掃流力(比例関係にある(4),6),7，9)。つ まり，底泥は個々の粒子ではなく，土塊として の強度が重要である。

ただし，(2)については，底泥の巻き上げ特性は粒 子表面に付着した陽イオンにも影響を受けることが 知られている. 大坪 ${ }^{4}$ (はこの違いにより底泥を $2 つ$ のグループに分けた . 第一底泥グループはカオリナ イト主成分粘土, モンモリロナイト, 現地泥が属し 第二底泥グループはベントナイト主成分粘土が属す 現地泥としては特異なタイプである．したがって， 貯水池内に堆積した底泥も大半は第一底泥グループ のものであると推定されるので，ここでは吸着陽イ オンについては議論しない .

(3)について, 関根ら ${ }^{10)}$ は, 独自に開発した引張り せん断試験機で測定した粘着力と浸食速度は強い相 関関係があることを示した ここれらより，粘着性土 の浸食特性は土質力学的な指標で表現できるといえ

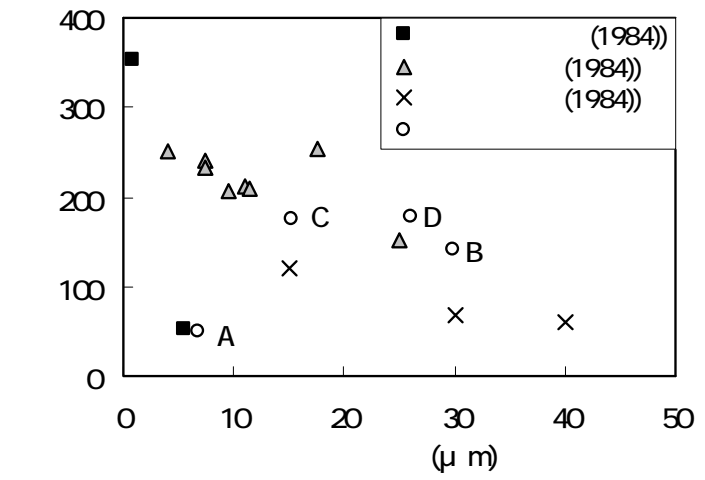

図- 3 中央粒径と液性限界の関係

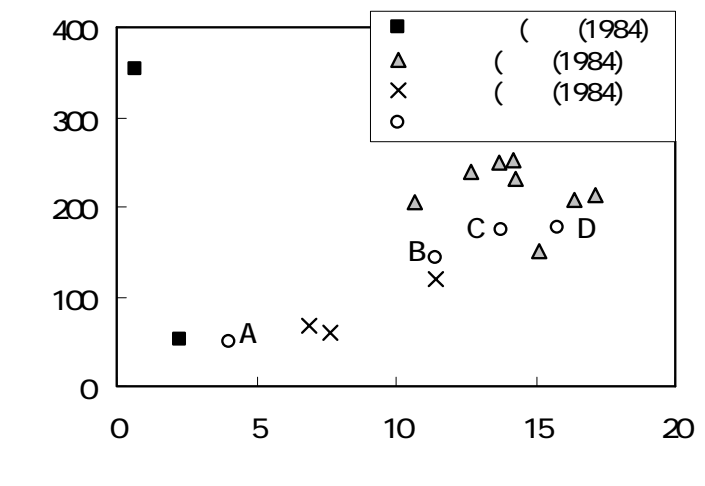

図-4 強熱減量と液性限界の関係

る. 本研究では, 各底泥固有の特性として, 液性限 界に注目した。

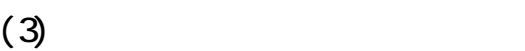

既往データより中央粒径, 強熱減量が異なると予 想された4公ムの底泥を流送実験の対象として選定 した .これらの底泥をエクマンバージ採泥器で採取 し, 粒度分布, 強熱減量, 液性限界, 土粒子密度, 自然含水比を測定した．弚の結果を表-1に示す．な お, 粒度分布はレーザー回折式粒度分析器 (HORI BA LA300）を使用した．また，ここでの自然含水比は 採泥器で採取された状態の底泥の含水比である．

ダムAの底泥は他の 3 つ試料と比較して, 大き く性質が異なる。中央粒径, 強熱減量, 液性限界, 自然含水比が小さく，土粒子密度が大きい.土粒子 密度が大きいのは, 密度の小さい有機物の含有量が 低く，密度の大きい粘土鉱物が多く含まれているか らである.ダムBの底泥は中央粒径が最も大きく， 見た目にも少し粗めの粒子が混合していた . ダムC， ダムDの底泥は中央粒径, 強熱減量の值は異なるが, 液性限界はほぼ等しい。

表-2は図- 2にプロットした大坪による底泥およ び粘土の物性値である.ダムAの底泥の物性はカ才 リンと比較的似ている．モンモリロナイトは中央粒 径, 強熱減量とも非常に小さく, 類似した物性か現 地泥では見られない。

これらの結果を用いて, 中央粒径, 強熱減量と液 性限界との関係をプロットしたものを図-3および 図-4に示す．図-3より, 強熱減量の小さいダムAの 底泥およびカオリンを除けば，中央粒径が小さくな 


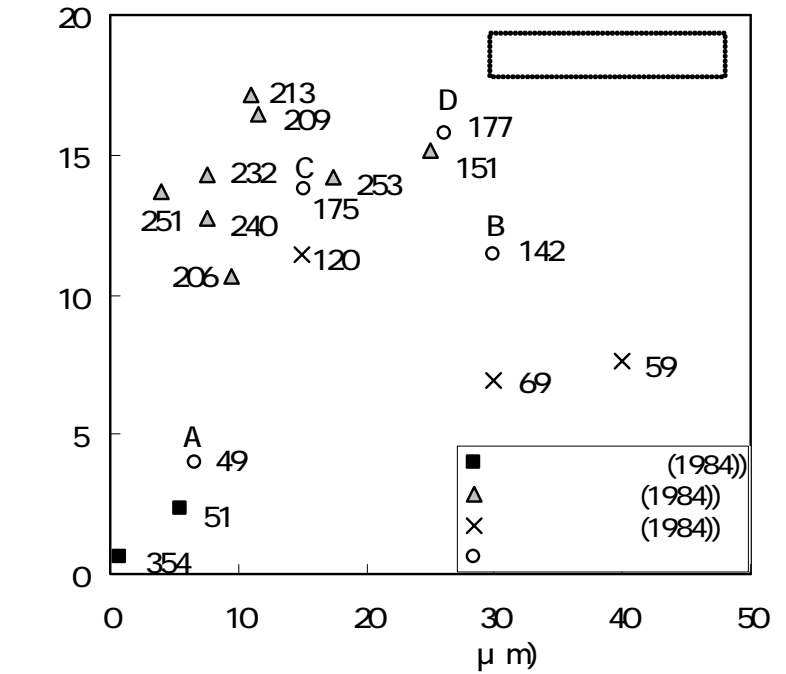

图- 5 中央粒径および強熱減量と液性限界の関係

るほど液性限界が大きくなる関係か確認できる．ま た, 図-4からは, 非常に粒径の細かいモンモリロナ イトを除けば, 強熱減量が増加するにしたがって液 性限界も大きくなる傾向が見られる .

図-5は横軸に中央粒径, 縦軸に強熱減量をとって プロットした点の隣に液性限界を記入している .こ れより，概してグラフの左上に位置する底泥の液性 限界が大きくなっているのがわかる . また , 中央粒 径が極端に小さいモンモリロナイトを除けば, 強熱 減量の值が支配的になっているようである .この分 布図より, 図-2に示された直轄30公么の底泥の液性 限界のおおよ光の值が推定でき，50\%から $250 \%$ の 間に分布していると予想できる.

\section{（4）流送実験}

\section{a) 装置の概要}

実験水路は透明アクリル製の長方形断面（高さ $35 \mathrm{~cm} x$ 幅 $15 \mathrm{~cm})$ で, 全長 $190 \mathrm{~cm}$, 流送区間は $100 \mathrm{~cm}$ ある . 水路の上端部から $70 \mathrm{~cm}$ のころに長さ $20 \mathrm{~cm}$ 幅15cmx 高さ5cmの移動床区間がある (图-6) . こ こに, 試料を充填した深さ1. $5 \mathrm{~cm}$ 試料箱を設置す る. 水路下流端には水位を変えるための流速制御板 を設置した . 水路上流端の給水部には流れを整流さ せるためのフィルターが設置してある . 水路の流速 は, 水中ポンプの電圧と下流の流速制御板を操作し て水深を調節し変化させる方法をとつた . 水路内の 流速はADV流速計を試料箱下流に設置して, 水路床 から1cm上方の流速データをPCに連続記録した 。

b) 実験方法

水槽に水を張らない状態で, 所定の含水比の底泥 を水路床に設置してから，試料を乱さないようゆっ くりと湛水する . 湛水後, 徐々に流速を上げ，底泥 の樣子を観察しビデオカメラに収める．また，試料 箱の下流側で計測した流速をもとに，流送限界 $\mathrm{T}$ c1 と破壞限界 $\mathrm{T}$ c2 を調べる．これらの定義は後述する

c) 実験条件

実験条件を表-3に示す. 各公の底泥の含水比を 3段階に調節したものを用意した .これらの含水比

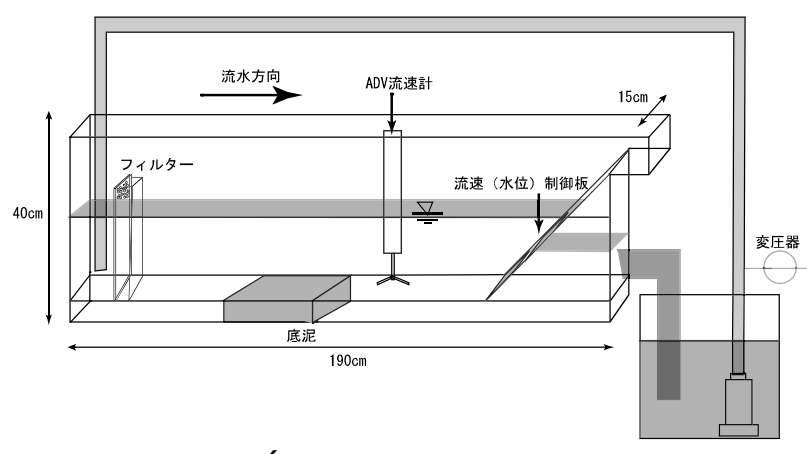

図- 6 実験装置の概要

表- 3 流送実験条件 (含水比)

\begin{tabular}{|c|c|c|c|}
\hline & 1 & 2 & 3 \\
\hline ダムA & $150 \%$ & $200 \%$ & $250 \%$ \\
\hline ダムB & $300 \%$ & $350 \%$ & $400 \%$ \\
\hline ダムC & $350 \%$ & $400 \%$ & $450 \%$ \\
\hline ダムD & $350 \%$ & $400 \%$ & $450 \%$ \\
\hline
\end{tabular}

は自然含水比に近く，かつ予備実験により今回の実 験装置で調整可能な掃流力により破壊限界がみられ る程度にしている。

d) 結果の整理方法

底面せん断応力は, 式(1)により算出した 。

$$
\tau_{b}=\rho_{w} C_{f} u^{2}
$$

ここに， $T_{b}$ は底面せん断応力 $\left(\mathrm{N} / \mathrm{m}^{2}\right) ， \rho_{w}$ は水 の密度 $\left(\mathrm{kg} / \mathrm{m}^{3}\right), C_{f}$ は底面摩擦係数， $u$ は流速 $(\mathrm{m} / \mathrm{s})$ である .このC $C_{f}$ は, 同じ水路で行った過去 の実験結果による底面から1cm上方の流速と底面せ ん断応力の関係を参考に，0.0032として底面せん断 応力を求めた。

\section{3 . 実験結果および考察}

（1）底泥の流送形態

a) 流送限界と破壞限界の定義

全ての試料に共通して，水を流し始めるとすぐに， 河床に目立った変化がなくとも，表面からごく小さ な粒子が溶け出すように少しずつ出ていく．通水後， 表面に少し粗めの粒子か増えることでも確認された . この観察結果より, 粘土・シルトのような微細粒子 には砂粒のように定義される限界掃流力は存在しな いといえる .これは，Part heni dades ${ }^{11)} の$ 粘土粒子 間の結合力は殆どゼ口に近い結合から最大値までの 分布を持ち，いかなる小さなせん断応力下において も壊されるような結合が常に存在するという記述に 相当する現象である．同樣に，関根ら ${ }^{122}$ はこの低流 速下での浸食を「単体での溶出」として「煙状の溶 出」や「塊状の剥離浸食」と区別している．一方， 大坪 ${ }^{4}$ は, 流送限界は底泥粒子が浮上し始める限界 であり，現象的には砂粒の限界掃流力に対応すると 定義している.今回の実験では，光のような限界は 確認されなかったことと，大坪の流送限界では表面 はがれが生じるという記述から，本研究では流送限 界を層状の表面剥離が始まるせん断応力と定義した . 
破壞限界は大坪の定義と同じく，底泥表面が破壊し て, 大量の底泥が短時間に流送される限界とした． 本研究は, 貯水池内の流速場により底泥の流送を促 進させて堆砂を軽減させることが目的であるので， 破壊限界がより興味ある值である .

b) 流送限界までの河床の変化

公 $\mathrm{B}, \mathrm{C}$ おびDの底泥は含水比に関係なく流送 限界までほほ類似した変化が観察された。まず，底 面流速が $5 \mathrm{~cm} / \mathrm{s}$ 程度から表層に露出された非常に小 さな木の葉の断片など軽い粒子が動き始める. そ光の 後, 光の動きが活発になると共に, 表層の極微細粒 子の溶け出しにより, 裸眼で確認できるような少し 粗めの粒子が表層に現れる．さらに，底面流速が $10 \mathrm{~cm} / \mathrm{s}$ を過ぎた頃から光れらの粒子か転がり始める 谷の後の流送限界が異なっても，ほぼ等しいせん断 応力下でこれらの過程か観察された .

ダムAの含水比 $150 \%$ のケースは類似した現象が見 られたが, 軽い粒子や粗めの粒子の含有量が低いこ とや, 粘着力か弱いことから, 表面の粒子の転動よ りも極微細粒子の溶け出しが顕著であった .さらに 含水比が $200 \%$ と $250 \%$ のケースでは, 河床表面は流 動性が高く，極微細粒子の溶け出しのみ観測された . c）流送限界から破壞限界までの河床の変化

ダムAの含水比 $200 \%, 250 \%$ 以外のすべてのヶー スで層状の表面剥離が生じた . 数十 $\mu$ mから数百 $\mu \mathrm{m}$ 程度の厚さの層が表面に形成されているようである この厚みは粘着性が高いものほど厚くなる傾向がみ られた . 試料や流れの不均一から底泥表層の一部に 剥離が生じ, 剥離した周囲の表層は流れに抵抗を受 けながら, 数m程度の大きさで引き離されていく. この剥離面の下に現れた河床は, 初めはあばた状で あるが, 時間の経過と共に, 剥離された表層と同じ ような薄い層を形成する .この一連の現象より，河 床表面では掃流力を受けて含水比が元の試料より低 くなった状態でクラスタを形成していると推定でき る.なお，通水後に表層の含水比が低下する現象は， 海田ら”の研究で確認されている.

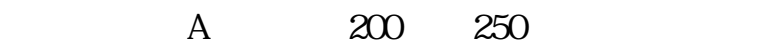
のような表層が明確に形成されないため，流送限界 が確認できなかった .

d) 破壞限界での河床の変化

クラスタを形成した表層はそ深河床よりも強 度が大きいと想定できるので, 破壊限界に到るまで は, 表層の結合力の弱い箇所が剥離しても，新たに 現れた河床面にクラスタの形成を許す程度のせん断 応力であると考えられる．さらに，破壤限界に達す ると, 河床を掘り下げるように浸食が進み, 濁度は 急上昇する .これに対して, ダムAの含水比 $200 \%$ ， $250 \%$ の底泥は, 河床面が上下に摇れ始め, 破壊限 界に到った。

\section{（2）限界掃流力}

各ケースの流送限界 ${ }_{\mathrm{c} 1}$, 破壊限界 ${ }_{\mathrm{C}}{ }_{\mathrm{C}}$ と含水比 との関係を図- 7 , 図-8に示す (ダム名のアルファ
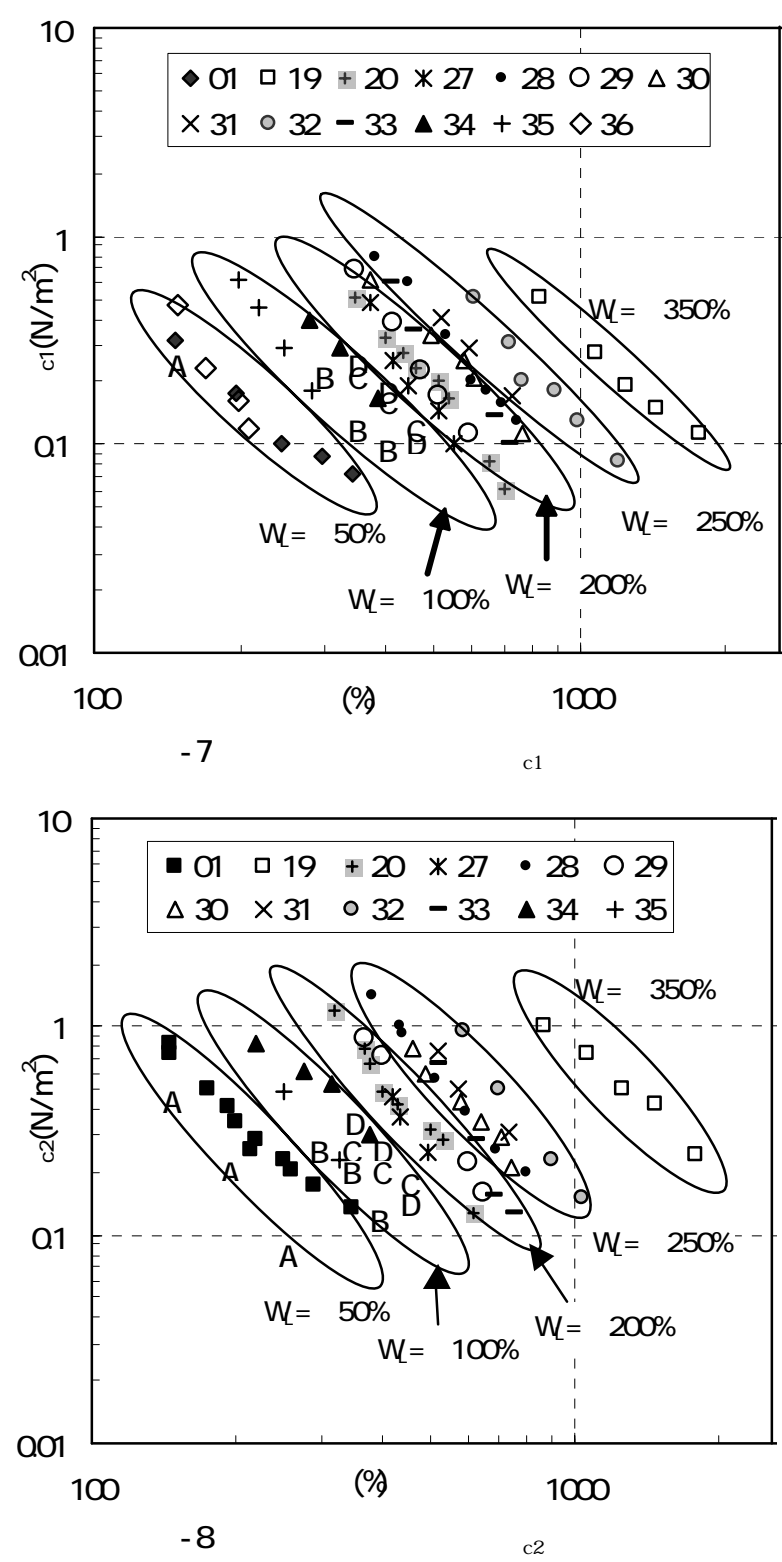

ベットが今回の実験結果のプロット点を示す) .こ れらのグラフには大坪による実験結果を併示してい る.なお , グラフの凡例の番号は表-2に対応する .

今回の実験結果も, 既往の研究と同樣に, T $\mathrm{c}_{1}$, $\mathrm{T}{ }_{\mathrm{c} 2}$ と含水比は両対数紙上でおおよ光直線関係と なった . 貯水池の底泥においても，含水比が高いほ ど，粘着性は弱くなり，小さな掃流力で巻き上がる ことが示された . 貯水池下流部の密度流堆積層は, 河口や浅い湖沼とは異なり，平常時は殆ど流れのな い静かな状態である．したがって，含水比の変化は 沈降した微細粒土砂が圧密されていく過程に対応し， 堆積して間もない底泥は巻き上げられやすいが , 時 間経過にしたがって含水比が小さくなり，巻き上げ には大きな力が必要になると言える .

液性限界の最も低かったダムAは, 同じ含水比で あれば，対象4ダムの底泥の中では最も巻き上がり やすく, 含水比の変化に敏感である.このグラフで のみ比較すると, 父么Aの底泥は再浮上しやすい性 質のように見える.しかし, 自然含水比が85\%と低 
いことから，圧密されやすい (有機物が少なく排水 性が高い) 性質であるのではないかと思われる.自 然含水比で比較すると最も巻き上げられにくい底泥 である.ただし，この自然含水比はエクマンバージ 採泥器で採取された底泥の含水比であり，採取され た底泥の上方に浮泥層がある可能性もある．

ダムCとDの底泥は表-1に示すように，中央粒径， 強熱減量は異なるが流送形態は類似し， T $\mathrm{c}_{1}, \mathrm{~T}$ c2 もほぼ同じ值となった．また，液性限界もほぼ等し い. ダムBの底泥は $\mathrm{T}_{\mathrm{c} 1}, \mathrm{~T} \mathrm{c}_{\mathrm{c}}$ および液性限界ともダ 厶C, Dの光れより少し小さな值をとつたが, 傾向は 似ている.これら3種の底泥の自然含水比における T 。2はほぼ等しく $0.25 \mathrm{~N} / \mathrm{m}^{2} て ゙ あ り ，$ 実験水路の底面 の流速にすると $28 \mathrm{~cm} / \mathrm{s}$ に相当する . 貯水池内でも同 じような条件て堆積しているとすれば，底部放流管 を開放してこの程度の底面せん断応力が発生すれば， 微細粒土砂は大量に巻き上げられ排出される可能性 がある.ただし, 現段階では, 小枝や木の葉の混入 や生物的な結合作用など現地の状態と実験条件との 違いが及ぼす影響は検討できていない .

4ダムの底泥を用いた実験から，貯水池下流部に 堆積した微細粒土砂でも，公により炎の巻き上げ 特性は異なることが分かった。特に, ダムAの底泥 の特性は他の 3 父么のものと大きく異なり，これは 有機物の含有量の影響を受けていると考えられる .

次に, 大坪の実験結果と合わせて考察すると, 液 性限界によって，おおよ光限界掃流力が区分できる ことが分かった . 図-7, 図-8に分類した結果を楕円 で囲んで示す．これより，液性限界を調べると，光 の底泥の含水比と限界掃流力の関係を予測すること ができる.さらに，この分類と図-5に示した中央粒 径, 強熱減量と液性限界の関係を用いると, 定期的 な採泥調査結果から，対象ダムの底泥の特性を知り 液性限界と含水比を介して限界掃流力の概略值を評 価することが可能となる .

以上, 貯水池の底泥の再浮上条件について議論し てきたが，浸食速度を議論するには至らなかった． 今回の実験範囲においては, 浸食過程が大きく3過

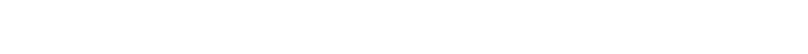
適用される浸食速度式も異なると考えられるが, 貯 水池の土砂管理の観点からは, 破壊限界以上の浸食 速度が重要となる. 既往の研究例えば7，12)，13)より， 浸食速度は底面せん断応力の1〜2乗程度に比例する ことが知られている.これらを参考に, 貯水池の底 泥の浸食速度について検討していく必要がある．

\section{4.おわりに}

ダム貯水池の微細粒土砂の管理に向けて, 基礎的 物性および巻き上げ特性について調べた .この研究 で得られた主要な結果をまとめると次のようである (1) 公貯水池により, 底泥の巻き上げ特性は異な り，弚の主たる要因は有機物含有量である .

(2) 同じダムの底泥でも, 含水比の減少 (圧密の進 行)にしたがって限界掃流力は増加する .
（3）底泥毎に異なる限界掃流力と含水比の関係は， その底泥の液性限界からおおよ光予測できる。

(4) 液性限界は, 強熱減量, 中央粒径と関係がある ことより，強熱減量，中央粒径が分かれば，お およ关の流送特性が推定できる.

また , 以下のことを今後の課題とする .

・基本的物性值の異なる他公么についても同樣の 実験および浸食速度測定を行い比較検討する。

- 本研究では, 含水比を調整した摚乱試料を流送 実験に使用した．有機分の多い底泥では，生物 的な結合も限界掃流力に関係する可能性がある ため，攪乱による影響を調べる．

・実際現地での巻き上がりを議論するには, 現地 での含水比の鉛直分布（つまり，圧密過程）お よび底部放流管開放時における貯水池底面の流 速特性を把握する必要がある.

謝辞: 本研究を行うにあたり，(独) 水資源機構関西 支社の管理ダムより貯水池内の微細粒堆積土砂をご 提供頂いた。 .また, 水理実験においては(株)ハイド ロシステム開発および京都大学工学研究科中西義昭 君の協力を得た .ここに記して謝意を表する。

\section{参考文献}

1) 大矢通弘, 角 哲也, 嘉門雅史 : ダム堆砂の性状把 握と弚の利用法, 公工学, Vol.12/No. 3, pp. 174 187, 2002.

2) Morris, G.L. and Fan, J.: Reservoir Sedimentation Handbook, McGraw Hill, Chapter 14, Turbid Density Current, 1997.

3) 中川康之, 渡邊和重, 谷川晴一, 黑田祐一: 海底面 近傍における底泥密度の鉛直分布特性の把握，海岸 工学論文集, 第51巻, pp. 986-990, 2004.

4）大坪国順：底泥の再浮上機構に関する基礎的研究, 京都大学学位論文, 1984.

5) Lick, W, Jin, L. and Gailani, J.: Initiation of Movement of Quartz Particles, J. Hydraulic Eng., ASCE, pp.755-761, 2004.

6) 梅田信, 高峰一, 石川忠晴, 大滝諭, 市山誠: 霞ヶ 浦底泥の洗掘過程に関する実験的研究, 土木学会論 文集, No. 740/II-64, pp. 63 73, 2003.

7) 海田輝之, 楠田哲也, 二渡了, 栗谷陽一: 柔らかい 底泥の巻き上げ過程に関する研究, 土木学会論文集, Vol. 393/II- 9 , pp. 33 $42,1988$.

8) 中野晋, 喜田将司：底泥の降伏値・移動限界に及ぼ す細砂混入の影響, 水工学論文集, 第40巻, pp. 959$964,1996$.

9）鶴谷広一, 江口秀二, 鷹濱潤 : 流れと波による底泥 の巻き上げに関する実験的研究, 第35回海岸工学講 演会論文集，pp. 357-361，1988。

10) 関根正人, 藤尾健太, 片桐康博, 西森研一郎: 粘着 性土の浸食速度に及ぼす粘着力の影響，水工学論文 集，第46巻, pp. 641- $646,2002$.

11) Partheniades, E.: Erosion and deposition of cohesive soils, J. Hydraulics Division, ASCE, pp.105-139,1985.

12）関根正人, 西森研一郎, 安藤史紘 : 粘着性土の浸食 過程と光れに与える乾燥湿潤履歴の影響，水工学論 文集，第48巻，pp. 937-942，2004.

13）板倉忠興: 粘着性土河床の洗掘, 第2回粘着性土の浸 食に関するシンポジウム論文集 , pp. 1- 6, 2004.

(2005. 9. 30受付) 